\title{
THE OCCURRENCE OF INSECTS AND MOULDS IN STORED COCOA BEANS AT SOUTH SULAWESI
}

\author{
OKKY S. DHARMAPUTRA \\ SEAMEO BIOTROP, P.O. Box 116, Bogor 16001, Indonesia, and \\ Department of Biology, Faculty of Mathematics and Natural Sciences, \\ Bogor Agricultural University, Bogor, Indonesia
}

SUNJAYA, MUHAMMADAMADANDINARETNOWATI

SEAMEO BIOTROP, P.O. Box 116, Bogor 16001, Indonesia

TEGUHWAHYUDI

The Indonesian Research Institute for Coffee and Cocoa, Jl. PB Sudirman 90, Jember 68118, Indonesia

\begin{abstract}
Surveys on postharvest handling and technology processing of cocoa beans at farmer, trader and exporter levels in South Sulawesi were conducted together with investigations on moisture content, pest infestation (insect and mould) and quality characteristics in terms of reducing sugar, free amino acid and free fatty acid content.

Surveys were conducted during dry (July 1997) and wet seasons (February 1998) in three regencies (Pinrang, Polewali-Mamasa and Luwu) and Ujung Pandang, South Sulawesi province. Interviews were carried out during surveys in the dry season. Number of respondents from farmers, trailers and exporters was 38,15 and 5 , respectively. In each season, number of samples taken from farmers, traders and exporters was 9, 21 and 15, respectively. In general, farmers, traders and exporters did not carry out postharvest handling and technology processing properly. Moisture content of cocoa beans collected from farmers, traders and exporters were higher than the tolerable limit recommended by SNI (7.5\%). Moisture content of cocoa beans collected during the wet season was higher than in the dry season.

Insects were found on cocoa beans collected from traders and exporters. Species composition and the presence of each insect species were varied among the two seasons, but the predominant species was Tribolium castaneum. At trader level the percentage of insect-damaged beans during the wet season was higher than that during the dry season, while at exporter level it was lower.

During the two seasons the percentage of mouldy beans at farmer level was lower than the tolerable limit recommended by SNI (4\%), while those from some samples at trader and exporter levels were higher than $4 \%$, but based on the direct plating method, all of the samples at trader and exporter levels were mouldy.

Species composition and the percentage of beans infected by each mould species at farmer, trader and exporter levels during the two seasons were varied. The percentage of mouldy beans increased at trader and exporter levels. The predominant moulds were Aspergillus flaws, Eurotium amstelodami, E. chevalieri and Penicillium citrinum. The predominant mould at farmer level during wet season was Saccharomyces cerevisiae (yeast).

Reducing sugar and free amino acid content of cocoa beans collected during the dry season was higher than those collected during the wet season, either at farmer, trader or exporter levels. Free fatty acid content of cocoa beans tends to be higher during the wet season than the dry season at the three levels.
\end{abstract}

Keywords: Stored products pests/Postharvest handling/Technology processing/Moisture content/Insect/Mould/Reducing sugars/Free amino acids/Free fatty acids/Cocoa/South Sulawesi. 


\section{INTRODUCTION}

Indonesia ranks third among the cocoa producing countries in the world after Ivory Coast and Ghana (ICO 1996). In South and Southeast Sulawesi cocoa production was dominated by smallholders, and generally the quality was low, i.e. high moisture content, low fat content, less flavour, and inconsistency in the quality of beans (Wahyudi 1994). In relation to health and food safety to consumers due to insect infestation and mould infection, the quality of cocoa beans in Indonesia is considered low (Siswoputranto 1994). Zaenudin and Wahyudi (1996) also reported that the problem of exported cocoa beans was due to insect infestation and mould infection, so that it was subjected to automatic detention, and thus should be refumigated.

The quality of cocoa beans can be increased by improving the method of postharvest handling from farmer to exporter levels. Aziz (1996) assumed that the low quality of cocoa beans was attributed to farmers and traders in Indonesia who did not conduct postharvest handling and technology processing properly.

The objective of this study was to get information on postharvest handling and technology processing of cocoa beans at farmer, trader and exporter levels in South Sulawesi province. The moisture content, pest infestation (insect and mould) and quality characteristics (reducing sugar, free amino acid and free fatty acid content) of cocoa beans were also analyzed.

\section{MATERIALS AND METHODS}

\section{Time and location of surveys}

Surveys were conducted during the dry (July 1997) and wet seasons (February 1998) in three regencies (Pinrang, Polmas and Luwu) and Ujung Pandang, South Sulawesi province. These districts were selected because they produce large quantities of cocoa beans, while Ujung Pandang was the main port for exporting of cocoa beans. Range of the number of rainy days and rainfalls from those regencies during dry and wet seasons is presented in Table 1. Interviews using questionnaires with farmers, traders and exporters, on the spot observation at survey locations, and random sampling of cocoa beans derived from farmers, traders and exporters in selected areas were carried out during the surveys.

\section{Interviews using questionnaires}

Interviews were carried out during the dry season to get information on postharvest handling and technology processing of cocoa beans at fanner, trader and exporter levels. Data were collected randomly from interviews with respondents. Number of respondents from each level was different depending on the condition in 
The Occurrence of Insects and Moulds in Stored Cocoa Beans - Okky S. Dharmaputra et al.

Table 1. Range and average number of rainy days and rainfall on location of the surveys during dry and wet seasons

\begin{tabular}{|c|c|c|c|c|c|c|c|c|}
\hline \multirow{2}{*}{} & \multicolumn{5}{|c|}{ Dry season } & \multicolumn{3}{c|}{ Wet season } \\
\cline { 2 - 9 } & \multicolumn{2}{|c|}{ June 1997 } & \multicolumn{2}{c|}{ July 1997 } & \multicolumn{2}{c|}{ January 1998} & \multicolumn{2}{c|}{ February 1998} \\
& RF & RD & RF & RD & RF & RD & RF & RD \\
\cline { 2 - 9 } & & & & & & & & \\
\hline Range & $49-155$ & $3-11$ & $68-106$ & $4-14$ & $85-175$ & $8-10$ & $138-264$ & $8-10$ \\
\hline Average & 91.3 & 6.0 & 82.7 & 8.7 & 135.4 & 8.7 & 207.3 & 9.3 \\
\hline
\end{tabular}

$\mathrm{RF}=\operatorname{rainfall}(\mathrm{mm})$

$\mathrm{RD}=$ rainy days (day)

the field during the surveys. Number of respondents at farmers, traders and exporters was 38, 15 and 5, respectively. The questionnaires contain questions on postharvest handling and technology processing carried out by farmers, traders and exporters.

\section{Sampling methods}

About $1 \mathrm{~kg}$ of each sample was taken randomly from farmer, trader and exporter levels. In each season, number of samples taken from farmers, traders and exporters were 9, 21 and 15, respectively. Samples of cocoa (primary samples) from each stack were taken randomly from a certain number of sacks using a sampling spear. Insects were separated from each primary sample using graded sieves. Each primary sample was divided several times using a sample divider to obtain working samples for analyzing moisture content, insect-damage, mould and quality characteristics in terms of reducing sugars, free fatty acids and free amino acids. The presence of insects was estimated on sack surface as well as within the sacks.

\section{Moisture content, insect, mould and quality characteristics analyses}

Moisture content (wet weight) was determined based on SNI 01-2323 (ISC 1995). The insects were identified using the publication of Haines (1991) as the main reference. Insect-damaged beans were determined according to SNI 01-2323 (ISC 1995).

Mouldy beans were determined based on 2 methods, namely cut test (ISC 1995) and direct plating methods on Dichloran 18\% Glycerol Agar (DG 18) (Pitt and Hocking 1985). The moulds were identified using the publications of Pitt and Hocking (1985), Samson et al. (1996) as the main references.

Reducing sugars, free amino acids and free fatty acids were determined according to Somogyi (McCready 1970), spectrometry method (Lillevik 1970) and SNI 01-2323 (ISC 1995), respectively. 
BIOTROPIA No. 12, 1999

\section{RESULTS AND DISCUSSION}

\section{Interviews with farmers, traders and exporters}

The results of questionnaires are shown in Table 2. Commonly, bulk cocoa was cultivated by smallholders in Pinrang, Polmas and Luwu regencies (99.4\% of

Table 2. Result of questionnaires on postharvest handling and technology processing of cocoa beans at farmer, trader and exporter levels

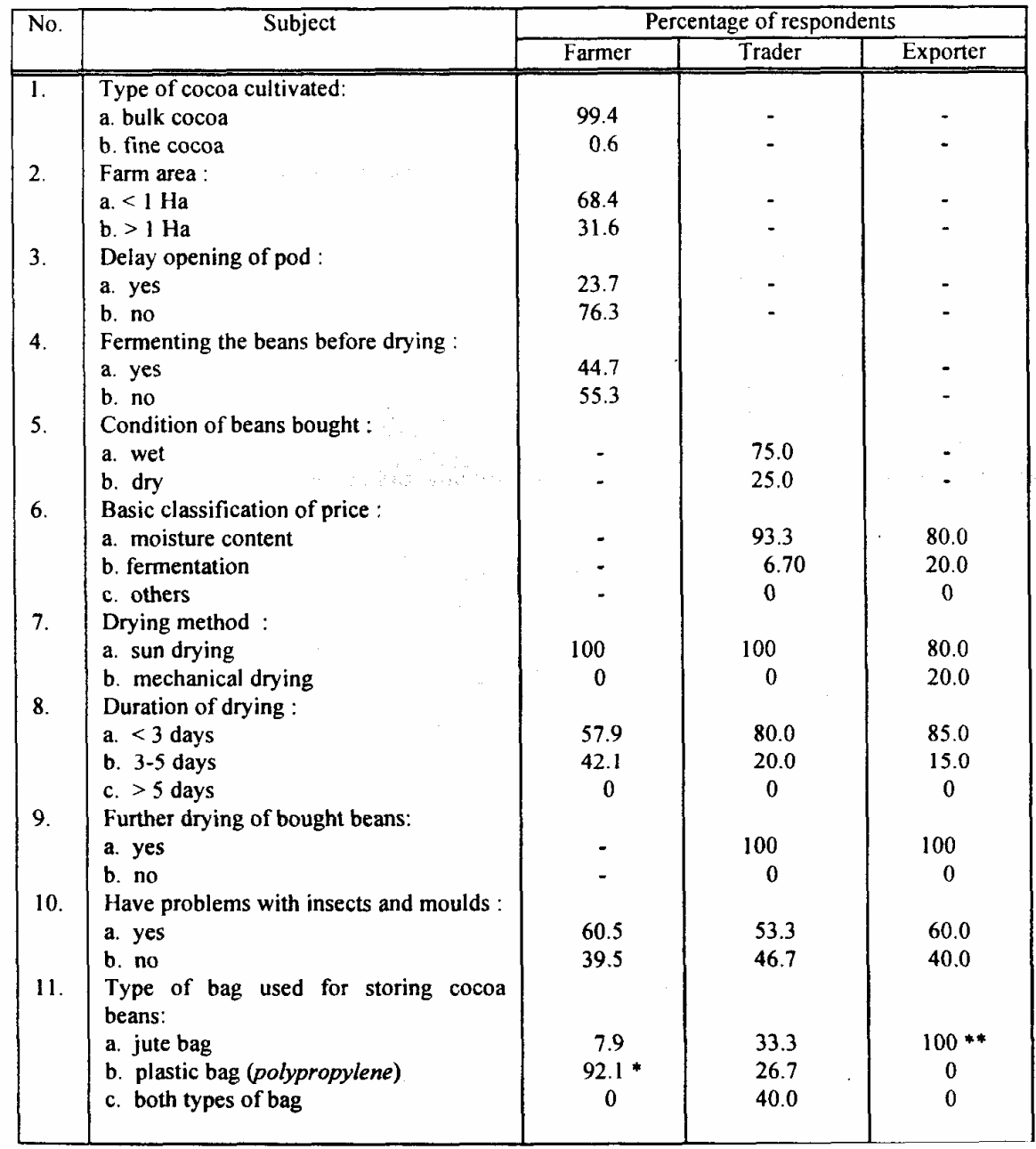

* = generally, ex fertilizer bag

** = generally, ex sugar bag 
respondents). Immediately after harvesting, the pods were opened using a knife or a wooden billet. Nevertheless, some farmers delayed opening the pods for several days (23.7\%).There were only $44.7 \%$ of farmers who fermented their cocoa beans properly before drying. Usually, the beans were fermented using traditional fermenting boxes.

Most of the traders bought wet cocoa beans from farmers (75\% of respondents), consequently farmers did not dry their cocoa beans up to recommended moisture content (7.5\%). Method of drying used by farmers was usually sun-drying for less than 3 days (57.9\%), or 3-5 days (42.1\%). They spread the beans on various drying facilities, namely fish net, jute bag, polypropylene bag, wooven bamboo and pandanus mat. Traders redried their cocoa beans for less than 3 days (80\%), consequently the moisture content was still high and the beans could easily be infected by mould. In this condition, cocoa beans could not be stored for a long time.

The common bag type used for storing cocoa beans at trader level was jute bag (33.3\%) ex fertilizer and sugar bags. Exporters also redried their cocoa beans by the sun-drying method, but during the wet season they used a mechanical dryer until $7.5 \%$ moisture content was attained. Jute bags were usually used to store the beans. Some exporters did not inspect the beans for insects and mould infestations in the warehouse.

\section{Moisture content a.}

\section{a. Farmer level}

Moisture content (m.c.) of cocoa beans collected from farmers during dry and wet seasons were 7.9-11.7\% (mean 9.7\%) and 9.3-14.0\% (mean 12.3\%), respectively (Table 3). Moisture content of the samples were higher than the tolerable limit recommended by SNI (7.5\%). Most of the farmers (75\%) sold cocoa beans in wet condition to the traders (Table 2). If the cocoa beans were not dried immediately and properly by the farmers, they could readily be infected by moulds. The farmers did not pay too much attention to the m.c. of cocoa beans sold, because they want to get money quickly. Their main source of living comes from cocoa beans.

Table3. Moisture content, insect-damage, and mouldy cocoa beans collected from farmers during dry and wet seasons

\begin{tabular}{|c|c|c|c|c|}
\hline \multirow[t]{2}{*}{ Parameter } & \multicolumn{2}{|c|}{ Dry season } & \multicolumn{2}{|c|}{ Wet season } \\
\hline & Mean & Range & Mean & Range \\
\hline $\begin{array}{l}\text { Moisture content (\%) Insect- } \\
\text { damage beans (\%) Mouldy beans } \\
(\%) \text { - cut test - direct plating } \\
\text { method }\end{array}$ & $\begin{array}{c}9.7 \mathrm{~b} 0 \\
0.2 \text { c } 18.4 \mathrm{e}\end{array}$ & $\begin{array}{l}7.9-11.7 \\
0-27-76\end{array}$ & $\begin{array}{c}12.3 \text { a } 0 \\
0.7 \text { c } 32.1 \mathrm{~d}\end{array}$ & $\begin{array}{l}9.3-14.0 \\
0-214-53\end{array}$ \\
\hline
\end{tabular}

Numbers followed by the same letter did not differ significantly according to Duncan Multiple Range Test at 95\% confidence level 
Based on statistical analysis, there was a significant difference between dry and wet seasons on m.c. of cocoa beans (Table 3). Aside from economical factors, the rainfall and the number of rainy days affected the duration of drying, so that the m.c. of cocoa beans during the wet season (12.3\%) was higher than during the dry season (9.7\%). Differences in rainfall and number of rainy days between wet and dry seasons are shown in Table 1.

\section{b. Trader level}

Moisture content of beans collected from traders during dry and wet seasons were 7.3-11.8\% (mean 9.4\%) and 7.3-12.9\% (mean 9.6\%), respectively (Table 4). M.c. of cocoa beans during the wet season was higher than the dry season, but based on statistical analyses the m.c. was not significantly different for the two conditions (Table 4). M.c. of almost all the samples collected (95.4\% samples) during dry and wet seasons were higher than $7.5 \%$ (tolerable m.c. for storing of cocoa beans). The traders redried the cocoa beans for less than 3 days, consequently their m.c. was still high, so that they could be infected by moulds.

Table 4. Moisture content, insect-damage, and mouldy cocoa beans collected from traders during dry and wet seasons

\begin{tabular}{|l|l|l|l|l|}
\hline \multirow{2}{*}{ Parameter } & \multicolumn{2}{|l|}{ Dry season } & Wet season \\
\cline { 2 - 5 } & Mean & Range & Mean & Range \\
\hline Moisture content (\%) & 9.4 a 0.2 b & $7.3-11.80-1$ & 9.6 a & $7.3-12.9,0-2$ \\
Insect-damage beans (\%) & $1.1 \mathrm{~d}$ 26.7 f & $0-85-100$ & $0.5 \mathrm{~b}$ & $0-73-100$ \\
Mouldy beans (\%) - cut test & & & 2.2 c 47.6 e & \\
- direct plating method & & & & \\
& & & & \\
\hline
\end{tabular}

Numbers followed by the same letter did not differ significantly according to Duncan Multiple Range Test at 95\% confidence level

\section{c. Exporter level}

Moisture content of cocoa beans collected from exporters during dry and wet seasons were 7.2-9.7\% (mean 8.2\%) and 7.5-11.5\% (mean 9.4\%), respectively (Table 5). Statistical analysis revealed that m.c of cocoa beans during the wet season was significantly higher than the dry season (Table 5). M.c. of twelve samples (80\%) collected during the dry season and all samples collected during the wet season were higher than $7.5 \%$. The high m.c. of cocoa beans collected from exporters during the wet season was due to the high m.c. of cocoa beans bought from traders. However, m.c. of cocoa beans always change with the change of relative humidity in storage. M.c. of $7.5 \%$ is in equilibrium with the relative humidity of storage of $75 \%$ (Wood 1985). 
The Occurrence of Jnsects and Moulds in Stored Cocoa Beans - Okky S. Dharmaputra el al.

Table S. Moisture content, insect-damage, and mouldy cocoa beans collected from exporters during dry and wet seasons

\begin{tabular}{|l|l|l|l|l|}
\hline \multirow{2}{*}{ Parameter } & \multicolumn{2}{c|}{ Dry season } & \multicolumn{2}{c|}{ Wet season } \\
\cline { 2 - 5 } & \multicolumn{1}{|c|}{ Mean } & \multicolumn{1}{c|}{ Range } & \multicolumn{1}{c|}{ Mean } & \multicolumn{1}{c|}{ Range } \\
\hline Moisture content (\%) & $8.2 \mathrm{~b}$ & $7.2-9.7$ & $9.4 \mathrm{a}$ & $7.5-11.5$ \\
Insect-damage beans (\%) & $0.7 \mathrm{c}$ & $0-3$ & $0.5 \mathrm{c}$ & $0-2$ \\
Mouldy beans (\%) & & & $1.7 \mathrm{~d}$ & $0-3$ \\
- cut test & $3.7 \mathrm{~d}$ & $0-6$ & $73.4 \mathrm{e}$ & $41-100$ \\
- direct plating method & $67.4 \mathrm{e}$ & $8-100$ & \\
\hline
\end{tabular}

Numbers followed by the same letter did not differ significantly according to Duncan Multiple Range Test at 95\% confidence level

\section{The presence of insects and insect-damaged beans}

Cocoa beans could be damaged by insects during storage, mainly of the orders Lepidoptera and Coleoptera. Kalshoven (1981) and Wood (1985) reported that insect species associated with stored cocoa beans were Araecerus fasciculatus (coffee bean weevil), Ephestia cautella (tropical warehouse moth), and Tribolium castaneum (rust red flour beetle). Insect pests of cocoa beans feed directly on grain constituents. Their feeding action causes loss of weight of the commodity, thus reducing its value, commercially and nutritionally. According to SNI 01-2323, insect-damaged beans should not be higher than $4 \%$. However, the quality of exported beans must be free from dead or live insects.

\section{a. Farmer level}

There were no insect-damaged beans and live insects found on cocoa beans collected from farmers during dry and wet seasons, because most of the farmers did not store the beans for a long time. Usually, soon after drying or storing for only less than 1 week, the beans were sold.

\section{b. Trader level}

Eight insect species found during the dry season were Anisopteromalus calandrae, Araecerus fasciculatus, Callosobruchus chinensis, Carpophilus sp., Cryptolestes ferrugineus, Liposcelis entomophila, Sitophilus zeamais and Tribolium castaneum. Ten insect species found during the wet season were Ahasverus advena, Anisopteromalus calandrae, Araecerus fasciculatus, C. chinensis, Carpophilus sp., L. entomophila, Oryzaephilus surinamensis, Palorus sp., S. zeamais and $T$. castaneum. Haines (1991) reported that these insects were major species infesting grain during storage, except $A$. calandrae which is a parasitic insect. Tribolium castaneum was the most frequently found insect. The percentages of samples infested by $T$. castaneum during dry and wet seasons were 66.7 and 71.4, respectively (Table 6). 
BIOTROPIA No. 12, 1999

Table 6. The number and percentage of cocoa bean samples infested by each insect species at trader level during dry and wet seasons

\begin{tabular}{|c|l|c|c|c|c|}
\hline \multirow{2}{*}{ N } & \multicolumn{2}{|c|}{ Insect species } & \multicolumn{2}{c|}{ Dry season } & \multicolumn{2}{c|}{ Wet season } \\
\cline { 3 - 6 } & $\begin{array}{c}\text { Number of in- } \\
\text { fested samples }\end{array}$ & $\begin{array}{c}\text { Percent of infested } \\
\text { samples }\end{array}$ & $\begin{array}{c}\text { Number of infested } \\
\text { samples }\end{array}$ & $\begin{array}{c}\text { Percent of infested } \\
\text { samples }\end{array}$ \\
\hline 1 & Ahasverus advena & 0 & - & 2 & 9.5 \\
\hline 2 & Anisoptermalus calandrae & 1 & 4.8 & 1 & 4.8 \\
\hline 3 & Araecerus fasciculatus & 5 & 23.8 & 3 & 14.3 \\
\hline 4 & Callosobruchus chinensis & 1 & 4.8 & 1 & 4.8 \\
\hline 5 & Carpophilus sp. & 1 & 4.8 & 2 & 9.5 \\
\hline 6 & Cryptolesles fernigineus & 1 & 4.8 & 0 & - \\
\hline 7 & Liposcelis entomophila & 1 & 4.8 & 1 & 4.8 \\
\hline 8 & Oryzaephilus surinamensis & 0 & - & 1 & 4.8 \\
\hline 9 & Palorus sp. & 0 & - & 2 & 9.5 \\
\hline 10 & Sitophilus zeamais & 3 & 14.3 & 4 & 19.0 \\
\hline 11 & Tribolium castaneum & 14 & 66.7 & 15 & 71.4 \\
\hline
\end{tabular}

Most of the traders sold various commodities in their shops which are located at traditional markets, consequently insect species of other commodities were also found on cocoa beans. Sitophilus zeamais and $C$. chinensis are the major insects associated with maize and mung beans. Their presence on stored cocoa beans was due to migration.

The difference among variability of insect species between dry and wet seasons was caused by the difference in physical conditions, such as temperature, relative humidity and moisture content. Haines (1991) reported that the development and behaviour of some insects could be affected by the physical condition of the environment. At high moisture content, competition between mould and other microorganisms could decrease the number of some stored insects which are replaced by fungus-feeder insects. In this study, this is shown by the presence of $A$. advena on 2 samples collected during the wet season. Percentage of insect-damaged beans in samples collected during the wet season $(0.5 \%)$ was higher than the dry season (0.2\%), but they were not significantly different (Table 4).

\section{c. Exporter level}

Seven insect species were found on cocoa beans collected during the dry season, they were A. fasciculatus, Bracon hebetor, Carpophilus sp., Corcyra cephalonica, Ephestia cautella, Necrobia rufipes and Tribolium castaneum, while during the wet season 10 insect species were found, i.e. Ahasverus advena, Araecerus fasciculatus, B. hebetor, Carpophilus sp., Corcyra cephalonica, Cryptolestes ferrugineus, E. cautella, Liposcelis entomophila, Oryzaephilus surinamensis and T. castaneum. Most of these insects were grain stored pest, except $B$. hebetor which is a parasitic insect of Corcyra cephalonica and E. cautella. Necrobia rufipes is a common insect associated with copra (Haines 1997), therefore 
its presence on stored cocoa beans was due to migration, because cocoa beans and copra were stored in the same warehouse. Variability of insect species at exporter level during the wet season was higher than the dry season. Tribolium castaneum was the most frequently found insect. The percentages of samples infested by $T$. castaneum during dry and wet seasons were 93.3 and 80.0, respectively (Table 7).

Table 7. The number and percentage of cocoa bean samples infested by each insect species at exporter level during dry and wet seasons

\begin{tabular}{|l|l|r|r|r|r|}
\hline \multirow{2}{*}{ Insect species } & \multicolumn{2}{c|}{ Dry season } & \multicolumn{2}{c|}{ Wet season } \\
\cline { 3 - 6 } & $\begin{array}{c}\text { Number of in- } \\
\text { fested samples }\end{array}$ & $\begin{array}{c}\text { Percent of infested } \\
\text { samples }\end{array}$ & $\begin{array}{c}\text { Number of infested } \\
\text { samples }\end{array}$ & $\begin{array}{c}\text { Percent of infested } \\
\text { samples }\end{array}$ \\
\hline 1 & Ahasverus advena & 0 & - & 5 & 33.3 \\
\hline 2 & Araecerus fasciculatus & 12 & 80.0 & 4 & 26.7 \\
\hline 3 & Bracon hebetor & 3 & 20.0 & 3 & 20.0 \\
\hline 4 & Carpophilus sp. & 1 & 6.7 & 2 & 13.3 \\
\hline 5 & Corcyra cephalonica & 1 & 6.7 & 2 & 13.3 \\
\hline 6 & Cryptolestes fermgineus & 0 & -7 & 2 & 13.3 \\
\hline 7 & Ephestia cautella & 8 & 53.3 & 1 & 6.7 \\
\hline 8 & Liposcelis entomophila & 0 & - & 1 & 6.7 \\
\hline 9 & Oryzaephilus surinamensis & 0 & - & 5 & 33.3 \\
\hline 1 & Necrobia rufipes & 1 & 6.7 & 0 & - \\
\hline 1 & Tribolium castaneum & 14 & 93.3 & 12 & 80.0 \\
\hline
\end{tabular}

The variability of insects found on cocoa beans at trader level, both during dry and wet seasons was different than at the exporter level. It might be due to the difference in environmental conditions. The structures and sanitary conditions of exporter's warehouses were better than that of trader's warehouse. Exporters usually stored only cocoa beans in their warehouse, while traders did not. According to Sidik (1997) the presence of pests in stored grain was usually affected by the physical structure and sanitary conditions of the storage facility, and characteristic of the stored grain. The percentage of insect-damaged beans during the wet season $(0.5 \%)$ was lower than the dry season $(0.7 \%)$, but they were not significantly different (Table 5).

\section{Mouldy beans}

The difference between the two analyzing methods (cut test/SNl and direct plating method) gave different results on mouldy beans. The percentage of mouldy beans using the cut test was lower than for the direct plating method, because the mould was invisible before it produces mycelium or spore mass inside the beans. Non- mouldy beans observed using the cut test might be already infected by mould, but their intensity was very low. Visual observation as well as examination of the beans using a stereoscopic microscope at low magnification also did not reveal the 
differences in the appearance of the beans that might be correlated with levels of mould infection. Niles (1981) reported that on invisible mouldy beans which had been further redried, the mould count was $2.0 \times 10^{\mathrm{s}} \mathrm{cfu} / \mathrm{g}$ beans. Nevertheless, Hanson and Welty (1971) stated that the presence of microorganisms on non-mouldy beans (visual observation) has no correlation with bean quality.

\section{a. Farmer level}

In general, farmers did not store the beans for a long period of time, therefore, the intensity of mould infection was still low. Statistical analysis showed that percentage of mouldy beans by the cut test was not significantly different between dry and wet seasons, while for the direct plating method it was significantly different (Table 3). The percentage of mouldy beans by the cut method during the wet season (32.1\%) was higher than the dry season (18.4\%). Mouldy beans obtained using the cut test during dry and wet seasons were between 0-2\%, respectively, while the direct plating method gave $7-76 \%$ and $14-53 \%$, respectively (Table 3 ). Cut tests showed that 1 sample (11\%) collected during the dry season and 5 samples (11\%) collected during the wet season had mouldy beans. Examination using the direct plating method showed that all of the samples had mouldy beans, during the two seasons. It suggests that mould infection has occurred at the farmer level, although its intensity was low.

Thirteen species of moulds were isolated from cocoa beans collected during the dry season, i.e. Aspergillus flavus, A. niger, A. ochraceus, A. restrictus, A. tamarii, $A$. wentii, Botryodiplodia theobromae, Cladosporium cladosporioides, Eurotium amstelodami, Mucor piriformis, Nigrospora oryzae, Penicillium citrinum and Saccharomyces cerevisiae (yeast). The predominant species were Aspergillus flavus and $A$. niger. Table 8 shows that the average number of beans infected by both

Table 8 . The percentage of cocoa beans infected by each mould species at farmer level during dry and wet seasons

\begin{tabular}{|l|l|c|c|c|c|}
\hline \multirow{2}{*}{ Mould species } & \multicolumn{4}{|c|}{ Infected beans (\%) } \\
\cline { 3 - 6 } & \multicolumn{2}{|c|}{ Dry season } & \multicolumn{2}{c|}{ Wet season } \\
\cline { 3 - 5 } & & Mean & Range & Mean & Range \\
\hline 1 & Aspergillus flavus & 10.4 & $0-67$ & 8.4 & $2-26$ \\
2 & A. niger & 10.4 & $0-59$ & 6.2 & $0-14$ \\
3 & A. ochraceus & 0.1 & $0-1$ & 0 & 0 \\
4 & A. reslriclus & 0.3 & $0-2$ & 0 & 0 \\
5 & A. tamarii & 0.5 & $0-3$ & 0.2 & $0-1$ \\
6 & A. wentii & 7.3 & $0-64$ & 0 & 0 \\
7 & Botryodiplodia theobromae & 1.7 & $0-7$ & 4.2 & $0-30$ \\
8 & Cladosporium cladosporioides & 1.8 & $0-6$ & 0 & 0 \\
9 & Eurotium amstelodami & 1.9 & $0-9$ & 5.1 & $0-20$ \\
1 & E. chevalier! & 0 & - & 2.6 & $0-13$ \\
1 & Mucor piriformis & 0.3 & $0-3$ & 0 & 0 \\
1 & Nigrospora oryzae & 0.2 & $0-2$ & 0 & 0 \\
1 & Penicillium citrinum & 5.6 & $0-19$ & 0.2 & $0-2$ \\
1 & Saccharomyces cerevisiae & 0.6 & $0-3$ & 34.4 & $0-100$ \\
\hline
\end{tabular}


species was $10.4 \%$. The other most frequently isolated moulds were $A$. Iventii (7.3\%) and Penicillium citrinum (5.6\%).

Eight species of moulds were isolated from cocoa beans during the wet season, i.e. A. flavus, A niger, A. tamarii, B. theobromae, E. amstelodami, E. chevalieri, $P$. citrinum and Saccharomyces cerevisiae. The percentage of the beans infected by each mould species is presented in Table 8 . The predominant moulds were $A$. flavus (8.4\%) and $A$. niger (6.2\%). On some samples, yeast was most frequently isolated. However, yeast did not give negative effects, because infection was only on the shell of cocoa beans due to improper washing and drying of the beans.

Botryodiplodia theobromae was isolated from cocoa beans collected from farmers. The presence of this mould indicated that the pods were infected by pod rot. According to Wood (1985) B. theobromae caused diplodia pod rot and infected the beans before harvest.

\section{b. Trader level}

Based on statistical analysis, the percentage of mouldy beans collected during the wet season was higher than that during the dry season and significantly different either using the cut test or the direct plating method (Table 4). Based on the cut test, mouldy beans obtained during the dry and wet seasons were $0-8 \%$ and $0-7 \%$, respectively. The percentage of mouldy beans using the direct plating method was higher than the cut test. The direct plating method yielded 5-100\% (mean 26.7\%) mouldy beans during dry season and 3-100\% (mean 47.6\%) during wet season (Table 4).

Based on the cut test, 2 samples $(0.1 \%)$ collected during the dry season and 4 samples $(0.2 \%)$ collected during the wet season had low quality, because the percentage of mouldy beans was more than $4 \%$. The direct plating method showed that all samples collected either during dry or wet seasons were mouldy.

The percentage of mouldy beans collected from the traders were higher than that from the farmers, because the traders did not carry out sorting properly. They also stored the beans with high moisture content for long time. Nineteen species of moulds were isolated from cocoa beans collected during the dry season, i.e. Aspergillus candidus, A. flavus, A. niger, A. ochraceus, A. restrictus, A. tamarii, A. -wentii, Botryodiplodia theobromae, Cladosporium cladosporioides, Eurotium amstelodami, E. chevalieri, Fusarium graminearum, F. proliferatum, Libertella faginea, Mucor piriformis, Nigrospora oryzae, Penicillium citrinum, Rhizopus oryzae, and Saccharomyces cerevisiae. The predominant moulds were A. niger (10.0\%), followed by P. citrinum (7.6\%) and A. flavus (5.6\%).

Fourteen species of moulds were isolated from cocoa beans collected during the wet season, i.e. Aspergillus candidus, A. flavus, A. niger, A. ochraceus, A. tamarii, Botryodiplodia theobromae, Cladosporium cladosporioides, Eurotium amstelodami, E. chevalieri, Libertella faginea, Mucor piriformis, Nigrospora oryzae, Penicillium citrinum and 5. cerevisiae. The predominant moulds were E. amstelodami (15.9\%) 
followed by A. flavus (12.6\%). The percentage of cocoa beans infected by each mould species is presented in Table 9 .

Table 9. The percentage of cocoa beans infected by each mould species at trader level during dry and wet seasons

\begin{tabular}{|l|l|c|c|c|c|}
\hline \multirow{2}{*}{ No } & \multirow{2}{*}{ Mould species } & \multicolumn{3}{|c|}{ Infected beans (\%) } \\
\cline { 3 - 6 } & & \multicolumn{2}{|c|}{ Dry season } & \multicolumn{2}{|c|}{ Wet season } \\
\cline { 3 - 5 } & & Mean & Range & Mean & Range \\
\hline 1 & Aspergillus candidus & 0.1 & $0-1$ & 0.1 & $0-3$ \\
2 & A. flavus & 5.6 & $0-58$ & 12.6 & $0-98$ \\
3 & A. niger & 10.0 & $0-96$ & 7.8 & $0-29$ \\
4 & A. ochraceus & 1.4 & $0-29$ & 0.1 & $0-3$ \\
5 & A. restrictus & 0.3 & $0-2$ & 0 & - \\
6 & A. tamarii & 0.4 & $0-2$ & 4.4 & $0-91$ \\
7 & A. wentii & 5.0 & $0-97$ & 0 & - \\
8 & Botryodiplodia theobromae & 1.7 & $0-11$ & 0.4 & $0-5$ \\
9 & Cladosporium cladosporioides & 1.8 & $0-9$ & 0.2 & $0-1$ \\
10 & Eurotium amstelodami & 2.4 & $0-16$ & 15.9 & $0-98$ \\
11 & E. chevalieri & 0.1 & $0-1$ & 4.3 & $0-88$ \\
12 & Fusarium graminearum & 0.1 & $0-2$ & 0 & - \\
13 & F. proliferatum & 0.4 & $0-3$ & 0 & - \\
14 & Libertella faginea & 0.6 & $0-3$ & 0.1 & $0-1$ \\
15 & Mucor piriformis & 0.7 & $0-4$ & 4.4 & $0-48$ \\
16 & Nigrospora oryzae & 0.2 & $0-3$ & 0.1 & $0-2$ \\
17 & Penicillium citrinum & 7.6 & $0-80$ & 1.6 & $0-8$ \\
18 & Rhizopus onyzae & 0.1 & $0-2$ & 0 & - \\
19 & Saccharamyces cerevisiae & 12.3 & $0-100$ & 15.0 & $0-99$ \\
\hline
\end{tabular}

Statistical analysis showed that there was no significant difference on the percentage of mouldy beans collected during dry and wet seasons, either using the cut test or the direct plating method (Table 5). The percentage of mouldy beans using the cut test and collected during dry and wet seasons were $0-16 \%$ (mean 3.7\%) and 0-3\% (mean 1.7\%), respectively, while those using the direct plating method were 8-100\% (mean 67.4\%) and $41-100 \%$ (mean $73.4 \%$ ), respectively (Table 5). Based on the cut test all samples collected during the wet season were still within the tolerable quality recommended by SNI 01-2323 (less than 4\%), except 1 sample collected during the dry season was higher than $4 \%$. Based on the direct plating method, all samples collected had mouldy beans in excess of $4 \%$, either during dry or wet seasons.

The percentage of mouldy beans collected from the exporters were higher than that from the traders. It was assumed that the exporters did not carry out sorting properly, or they stored the beans with high moisture contents, consequently the beans were more easily infected by mould. Sixteen species of moulds were isolated 
The Occurrence of Insects and Moulds in Stored Cocoa Beans - Okky S. Dharmaputra el al.

from cocoa beans during the dry season, i.e. Aspergillus candidus, A. Jlavus, A. niger, A. ochraceus, A. tamarii, A. wentii, Botryodiplodia theobromae, Cladosporium cladosporioides, Eurotium amstelodami, E. chevalieri, E. repens, Libertella faginea, Mucor piriformis, Penicillium citrinum, Rhizopus oryzae and Saccharomyces cerevisiae (Table 10). The predominant mould was P. citrinum (37\%). Other moulds frequently isolated were Eurotium amstelodami (31.5\%) and A. niger (13.3\%). The domination by P. citrinum and E. amstelodami was correlated with low moisture content of beans (about 8\%).

Eleven species of moulds were isolated from cocoa beans during the wet season, i.e. Aspergillus flavus, A. niger, A. tamarii, Cladosporium cladosporioides, Eurotium amstelodami, E. chevalieri, Libertella faginea, Mucor piriformis, $M$. racemosum, Penicillium citrinum and Rhizopus oryzae (Table 10). The predominant moulds were A. flavus (20.5\%) and E. chevalieri (20.9\%).

Table 10. The percentage of cocoa beans infected by each mould species at exporter level during dry and wet seasons

\begin{tabular}{|l|l|c|c|c|c|}
\hline \multirow{2}{*}{ No } & \multirow{2}{*}{ Mould species } & \multicolumn{4}{|c|}{ Infected beans (\%) } \\
\cline { 3 - 6 } & & \multicolumn{2}{|c|}{ Dry season } & \multicolumn{2}{c|}{ Wet season } \\
\cline { 3 - 6 } & & Mean & Range & Mean & Range \\
\hline \hline 1 & Aspergillus candidus & 0.3 & $0-4$ & 0 & - \\
2 & A. flavus & 10.1 & $0-79$ & 20.5 & $0-99$ \\
3 & A. niger & 13.3 & $0-95$ & 14.7 & $0-84$ \\
4 & A. ochraceus & 0.3 & $0-3$ & 0 & - \\
5 & A. tamarii & 0.8 & $0-5$ & 7.6 & $0-99$ \\
6 & A. wentii & 0.3 & $0-3$ & 0 & - \\
7 & Botryodiplodia theobromae & 0.9 & $0-3$ & 0 & - \\
8 & Cladosporium cladosporivides & 0.5 & $0-4$ & 0.4 & $0-2$ \\
9 & Eurotium amstelodami & 31.5 & $0-90$ & 18.2 & $0-57$ \\
10 & E. chevalieri & 10.1 & $0-100$ & 20.9 & $0-98$ \\
11 & E. repens & 0.3 & $0-2$ & 0 & - \\
12 & Libertella faginea & 0.1 & $0-1$ & 0.3 & $0-3$ \\
13 & Mucor piriformis & 1.6 & $0-11$ & 0.5 & $0-3$ \\
14 & M. racemosum & 0 & - & 1.3 & $0-13$ \\
15 & Penicillium citrinum & 37.0 & $0-100$ & 0.1 & $0-1$ \\
16 & Rhizopus oryzae & 0.3 & $0-2$ & 2.1 & $0-11$ \\
17 & Saccharomyces cerevisiae & 2.5 & $0-38$ & 0 & - \\
\hline
\end{tabular}

The quality requirements for both marketing and manufacturing stages can be divided into factors. Firstly, the yield-determining factors are bean size, shell content, fat content, and foreign matter. Secondly, the quality-determining factors are flavour, purity or wholesomeness, consistency, and cocoa butter characteristics. Quality analysis of cocoa bean samples in this study were conducted in terms of reducing sugars and free amino acids, whereas cocoa butter quality was represented by free fatty acids analysis. 
BIOTROPIA No. 12,1999

\section{Reducing sugars}

Reducing sugars (fructose and glucose), amino acids and peptides are flavour precursors (Biehl et al. 1985). Reducing sugars are important flavour precursors. The role of this sugar is to perform as a degrading agent of amino acids during flavour development (Rohan and Stewart 1967a). Hastori et al (1987) reported that reducing sugar content of cocoa beans correlated with the duration of fermentation. The results show that during the dry season they tend to be higher than the wet season, especially at farmer and trader levels (Table 11). These results imply that postharvest handling of cocoa beans should be conducted more carefully at farmer and trader levels, especially during the wet season, in order to produce higher reducing sugar content.

Table 11. Reducing sugar content of cocoa beans collected from farmers, traders, and exporters during dry and wet seasons

\begin{tabular}{|l|l|l|l|l|}
\hline \multirow{2}{*}{ Source of cocoa beans } & \multicolumn{3}{|c|}{ Reducing sugar content (\%) } \\
\cline { 2 - 5 } & \multicolumn{2}{|c|}{ Dry season } & \multicolumn{2}{c|}{ Reange } \\
\cline { 2 - 5 } & \multicolumn{2}{|c|}{ Mean } & \multicolumn{1}{c|}{ Mean } & \multicolumn{1}{c|}{ Range } \\
\hline Farmers & $1.32 \mathrm{a}$ & $1.05-1.51$ & $1.15 \mathrm{~b}$ & $1.04-1.340$. \\
Traders & $1.34 \mathrm{a}$ & $0.96-1.63$ & $0.93 \mathrm{~b} 1$. & $53-1.22$ \\
Exporters & $1.27 \mathrm{a}$ & $0.96-1.51$ & $19 \mathrm{a}$ & $1.03-1.47$ \\
\hline
\end{tabular}

Numbers followed by the same letter in the same row do not differ significantly according to DMRT a 95\% confidence level

Reducing sugar content of cocoa beans collected from farmers, traders an< exporters during the dry season were $1.05-1.51 \%$ (mean $1.32 \%$ ), $0.96-1.63 \%$ (mea $1.34 \%$ ) and $0.96-1.51 \%$ (mean $1.27 \%$ ), respectively, while during the wet seaso $1.04-1.34 \%$ (mean 1.15\%), 0.53-1.22\% (mean 0.93\%), and 1.03-1.47\% (mea $1.19 \%$ ), respectively (Table 11 ).

\section{Free amino acids}

As mentioned above, free amino acids constitute a flavour precursor. Roh and Stewart (1967b) revealed that flavour development of cocoa beans correlai with amino acid synthesis during fermentation. Hastori et al. (1987) reported t amino acid content could be affected by duration of fermentation. Therefr fermentation must be stopped when the condition of free amino acid content reached a maximum. Under-fermentation and over-fermentation cause loss of $s<$ precursors of flavour development.

The results of free amino acid analysis also show that during the dry se; they tend to be present at higher levels than the wet season. Statistical analysis sh that there was a significant difference between free amino acid content of $\mathrm{c}$ beans collected from farmers during dry and wet seasons, but neither from tn nor exporters (Table 12). 
The Occurrence of Insects and Moulds in Stored Cocoa Beans - Okky S. Dharmaputra et al.

Free amino acid content of cocoa beans collected from farmers, traders, and exporters during the dry season were $0.47-1.04 \%$ (mean $0.64 \%$ ), $0.15-1.26 \%$ (mean $0.66 \%$ ), and $0.44-1.50 \%$ (mean $0.76 \%$ ), respectively, while during the wet season $0.31-0.71 \%$ (mean $0.49 \%$ ), $0.41-0.84 \%$ (mean $0.59 \%$ ), and $0.42-1.14 \%$ (mean $0.68 \%$ ), respectively (Table 12 ).

Table 12. Free amino acid content of cocoa beans collected from farmers, traders, and exporters during dry and wet seasons

\begin{tabular}{|l|l|l|l|l|}
\hline \multirow{3}{*}{ Source of cocoa beans } & \multicolumn{4}{|l|}{ Free amino acid content (\%) } \\
\cline { 2 - 5 } & Dry season & Wet season & \multicolumn{2}{l|}{} \\
\cline { 2 - 5 } & Mean & Range & Mean & Range \\
\hline Farmers & $0.64 \mathrm{a}$ & $0.47-1.040 .15-$ & $0.49 \mathrm{~b}$ & $0.31-0.71$ \\
Traders & $0.66 \mathrm{a}$ & $1.260 .44-1.50$ & $0.59 \mathrm{a}$ & $0.41-0.84$ \\
Exporters & $0.76 \mathrm{a}$ & & $0.68 \mathrm{a}$ & $0.42-1.14$ \\
\hline
\end{tabular}

Numbers followed by the same letter in the same row do not differ significantly according to DMRT at 95\% confidence level.

\section{Free fatty acids}

The measurement of free fatty acids (ffa) provides an indication of the quality of cocoa beans to produce cocoa butter. Cocoa butter with high level of free fatty acids tend to be soft, have poor crystallization properties, contain off-flavour, and have a poor shelflife (Nickless 1994). The ffa level must be less than $1.0 \%$, so that ffa in the cocoa butter produced from these beans will be less than $1.75 \%$. This is the legal limit for cocoa butter within the EEC and the limit proposed by Codex (CCCA 1984).

The free fatty acid contents of cocoa beans collected from farmers, traders and exporters were higher during the wet season than the dry season (Table 13). This might be due to incomplete or delayed drying, long period of storage under humid conditions (CCCA 1984), or accidental wetting during storage, transport or shipment (Wood 1985). Based on statistical analysis, there were significant differences between ffa content of cocoa beans collected during the dry and wet seasons at farmer and exporter levels. These results also justified the need of a better postharvest handling technique at farmer, trader and exporter levels.

Free fatty acid content of cocoa beans collected from farmers, traders and exporters during the dry season were $0.25-2.19 \%$ (mean $0.90 \%$ ), $0.43-2.86 \%$ (mean $0.96 \%$ ), and $0.52-1.89 \%$ (mean $1.10 \%$ ), respectively, while during the wet season $0.29-1.83 \%$ (mean $1.45 \%$ ), $0.53-3.81 \%$ (mean $1.25 \%$ ), and $0.83-2.04 \%$ (mean $1.39 \%$ ), respectively (Table 13). The free fatty acid contents of cocoa beans collected from farmers, traders and exporters were higher during the wet season than the dry season. This might be due to incomplete or delayed drying, long period of storage under humid condition (CCCA 1984), or accidental wetting during storage, transport or shipment (Wood 1985). 
Table 13. Free fatty acid content of cocoa beans collected from farmers, traders, and exporters during dry and wet seasons

\begin{tabular}{|l|l|l|l|l|}
\hline \multirow{3}{*}{ Source of cocoa beans } & \multicolumn{4}{|l|}{ Free fatty acid content (\%) } \\
\cline { 2 - 5 } & \multicolumn{2}{|l|}{ Dry season } & Wet season & Range \\
\cline { 2 - 5 } & Mean & Range & Mean & $0.29-1.83$ \\
\hline Farmers & $0.90 \mathrm{a}$ & $0.25-2.190 .43 .-$ & $1.45 \mathrm{~b}$ & $0.53-3.81$ \\
Traders & $0.96 \mathrm{a}$ & $2.860 .52-1.89$ & $1.25 \mathrm{a}$ & $0.83-2.04$ \\
Exporters & $1.10 \cdot$ & & $1.39 \mathrm{~b}$ & \\
\hline
\end{tabular}

Numbers followed by the same letter in the same row do not differ significantly according to DMRT at 95\% confidence level.

\section{CONCLUSIONS}

In general, farmers, traders and exporters did not carry out postharvest handling and technology processing of cocoa beans properly. Moisture content of cocoa beans collected from farmers, traders and exporters were higher than the tolerable limit recommended by SNI (7.5\%). M.c. of cocoa beans during the wet season was higher than the dry season.

Insects were found on cocoa beans from traders and exporters. Species composition and presence of each insect species were varied during the two seasons, but the presence of Tribolium castaneum occurred at higher frequency. At trader level the percentage of insect-damage beans was higher during the wet season than the dry season, while at exporter level it was lower. Based on the cut test during the two seasons the percentage of mouldy beans at farmer level was lower than the tolerable limit recommended by SNI (4\%), while those from some samples collected at trader and exporter levels were higher than $4 \%$, but based on the direct plating method all of the samples collected at the two levels were mouldy.

Species composition and the percentage of beans infected by each mould species at farmer, trader and exporter levels during the two seasons were varied. The percentage of mouldy beans increased at trader and exporter levels. Aspergillus flavus, Eurotium amstelodami, E. chevalieri and Penicillium citrinum were the predominant moulds. The predominant mould isolated from cocoa beans collected from farmers during the wet season was Saccharomyces cerevisiae (yeast).

Reducing sugar and free amino acid content of cocoa beans collected during the dry season were higher than those collected during the wet season, either at farmer, trader or exporter levels. Free fatty acid content of cocoa beans tends to be higher during the wet season than the dry season at the three levels.

Postharvest handling of cocoa beans should be conducted more carefully at farmer, trader and exporter levels, especially during the wet season, in order to produce good quality cocoa beans. 
The Occurrence of Insects and Moulds in Stored Cocoa Beans - Okky S. Dharmaputra et al.

\section{ACKNOWLEDGEMENT}

The authors gratefully acknowledge the financial support of the Government of Indonesia. Thanks are due to the Plantation Office Province Level, South Sulawesi; Plant Quarantine Service, Ujung Pandang; and DPD ASKINDO South Sulawesi for their information and cooperation during the surveys at farmer, trader and exporter levels in South Sulawesi. The authors are also grateful to the Indonesian Research Institute for Coffee and Cacao, for their collaboration in this study.

\section{REFERENCES}

Aziz, M.F. 1996. Upaya peningkatan mutu biji kakao rakyat melalui sentralisasi pengolahan. Wart a Puslit Kopi dan Kakao 12(1): 12-17. BIEHL, B., E. BRUNNER, D. PASSERN, V.C. QUESNEL and D. ADOMAKO. 1985. Acidification, proteolysis,

and flavour potential in fermenting cocoa beans. J. Sci. Fd. Agric. 36 : 583-598. CCCA (The Cocoa, Chocolate and Confectionery Alliance). 1984. Cocoa beans: chocolates manufacturer's quality requirements. 11 Green Street, London, 20p. HAINES, C.P. 1991. Insects and Arachnids of Tropical Stored Products: Their Biology and Identification

(A Training Manual). Natural Resources institute, U.K. HAINES, C.P. 1997. Insects and arachnids in Indonesian food stores-biodiversity in a man-made

environment. Proceedings of the Symposium on Pest Management for Stored Food and Feed,

Bogor, Indonesia, 5-7 September 1995. p. 95-125. HANSOM, A.P. and R.E. WELTY. 1971. Microflora of raw cocoa beans. Mycopath. Mycol. Appl. 44 : 309-

316. HASTORI, B., DJATMIKO and T. WAHYUDI. 1987. Pengaruh perlakuan pendahuluan pada fermentasi

kakao (Theobroma cacao L.) terhadap mutu biji keringnya. Bul. Teknol. Industri Pertanian 1 (I) :

23-40. INDONESIAN STANDARDIZATION COUNCIL. 1995. Indonesian National Standard, SNI 01-2323-

1995, Rev. 1994: Cocoa Beans. INTERNATIONAL COCOA ORGANIZATION. 1996. Production of cocoa beans by country, 1986/87-

1995/96. Quart, bull, of cocoa statistics 22 (3): 6. International Cocoa Organization, London. KALSHOVEN, L.G.E. 1981. The Pests of Crops in Indonesia. Revised by P.A. Van der Laan. P.T. Ichtiar Baru-Van Hoeve, Jakarta. LILLEVIK, H.A. 1970. The analytical chemistry of the protein, peptides and amino acids. In Methods in

Food Analysis: Physical, Chemical and Instrumental Methods of Analysis (Ed. by Joslyn, M.A.),

2nd ed. Academic Press, New York. p. 617-700. Me CREADY, R.M. 1970. Monosaccharides. In Methods in Food Analysis: Physical, Chemical and

Instrumental Methods of Analysis (Ed. by Joslyn, M.A.), $2^{\text {nd }}$ ed. Academic Press, New York.

p. 475-509. NICKLESS, H. 1994. Cocoa butter quality. In Proceeding of The Malaysian International Cocoa

Conference (Ed. by J. Selamat, B.C. Lian, T.K. Lai, W.R.W. Ishak and M. Mansor). Malaysian Cocoa Board : 322-336.

NILES.E.V. 1981. Microflora of imported cocoa beans. J. Stored Prod. Res. 17:147-150. Pirr, J. I and A.D. HOCKING. 1985. Fungi and Food Spoilage. Academic Press, Sydney. ROMAN, T.A. and T. STEW ART. 1967a. The precursors of chocolate aroma : production of reducing sugars during fermentation of cocoa beans. J. Food Sci. 32:399-402. 1967b. The precursors of chocolate aroma : productions of free amino acid during

fermentation of cocoa beans. J. Food. Sci. 32: 395-398. SAMSON, R.A, E.S. HOEKSTRA, J.C. FRISVAD and

O. FLITENBORG. 19\%. Introduction to Food-Borne

Fungi. 3th ed. Centraalbureau voor Schimmelcultures, Baam, The Netherlands. 
SIDIK, M. 1997. State-of-the-art of storage management. Proceedings of the Symposium on Pest Management for Stored Food and Feed, Bogor, Indonesia, 5-7 September 1995. p. 11-23. SISWOPUTRANTO, P.S. 1994. Prospek perkakaoan dunia dan beberapa masalah yang perlu digarap. Makalah disampaikan dalam Gelar Teknologi Pascapanen Kakao Rakyat, Samarinda, 13-14 September 1994. WAHYUDI, T. 1994. Teknologi pengolahan untuk menghasilkan kakao bermutu baik dan usaha diversifikasi produk. Makalah disampaikan dalam Gelar Teknologi Pascapanen Kakao Rakyat. Samarinda, 13-14 September 1994. p. 1-17. wOOD, G.A.R. 1985. From harvest to store. In Cocoa. (Ed. by Wood, G.A.R and R.A. Lass). Longmann,

London, pp.444-504. ZAENUDIN and T. WAHYUDI. 1996. Laporan kunjungan tim ASKINDO ke Amerika Serikat dalam upaya meniadakan automatic detention terhadap kakao Indonesia. Warta Puslit. Kopi dan Kakao 12(1): 44-47. 